Journal of American Studies, 34 (2000), I, I I 5-1 36 Printed in the United Kingdom

(C) 2000 Cambridge University Press

\title{
"Who's The Mack?": The Performativity and Politics of the Pimp Figure in Gangsta Rap
}

\author{
EITHNE QUINN
}

Mack: pimp; talk someone into something

"Pimptionary," Ice-T ${ }^{\mathbf{1}}$

Mack man: Short for Mackerel man, a pimp. Possibly from the French maquereau. Connotes the working side of pimping, especially the line, the "rap," the psychological game.

\footnotetext{
"Pimp Talk," Christina and Richard Milner²
}

Mack, as these definitions attest, is synonymous with pimp and is so deployed in gangsta rap as both noun and verb. From this denotative meaning, the term has assumed secondary meanings: to persuade, or as Ice-T says "to talk someone into." The mack comes to mean the persuader, the trickster, the rapper. This semantic shift strikes at the centre of the equivalencies between rap artist and pimp. As music critic S. H. Fernando asserts, "the one specific quality that pimps and rappers share is their way with words. "3 If broad parallels can be drawn between pimping and rapping, what is distinctive about the notorious and highly successful subgenre of gangsta rap, which emerged in late-I980s urban California, is that here this equivalence is literalized. Many gangsta

Eithne Quinn is a lecturer in the Department of Cultural Studies, University of Central Lancashire, Preston PR I $2 \mathrm{HE}$.

I want to thank the British Association for American Studies for funding my research trip under the Short-Term Travel Award scheme, David Adams and the Bruce Centre for American Studies at Keele University, and also Steve Chibnall, Steven Daly, Mary Ellison, Lee Grieveson, Michelle Wright, and, above all, Peter Krämer. Thanks also to Too Short, Jeff Kempler, and Zomba Music Publishing for granting permission to reprint lyrics.

${ }^{1}$ Ice-T (with Heidi Siegmund), The Ice Opinion (London: Pan Books, 1994), 198.

${ }^{2}$ Milner and Milner, Black Players: The Secret World of Black Pimps (London: Michael Joseph, 1972), 303.

${ }^{3}$ Fernando, The New Beats: Exploring the Music, Culture and Attitudes of Hip-Hop (Edinburgh: Payback Press, i 995), i i6-I 7 . 
rappers actually assume pimp personae, presenting oral narratives which fulfil both denotative and connotative meanings of the word mack.

Pimp imagery proliferates in gangsta rap. Many artists adopt the role for whole tracks, becoming stylish, sexual hustlers: Notorious B.I.G. is "Big Poppa" ("Money, hoes, and clothes: all a nigga knows"); the group members of Above the Law are Vocally Pimpin'; Sir Mix-A-Lot is the "Mack Daddy" ("I don't want to hit 'em, just stick 'em"); and Ice-T's star image is predicated on macking, from "Somebody's Gotta Do It! (Pimpin' Ain’t Easy!!!)" in 1987 to "Pimp Anthem" in 1996. Some present literalized accounts of this occupation: Too Short is Shorty the Pimp ("If I ever go broke I just break hoes"); and Sylk Smoov has "Klientele." Others invoke the pimp lexicon to demean women (sometimes playfully, sometimes pornographically), indicated by the track titles "Gz [gangstas] Up, Hoes Down” by Snoop Doggy Dogg, "Bitches Ain't Shit (But Hoes and Trix)" by Dr Dre, and the comical "Treat Her Like a Prostitute" by Slick Rick. Still others take on the personae of retributive, violent pimps: Mr Scarface is "sendin bitches home with a limp," in "The Pimp"; and in a concerted effort to shock, stories of demeaning and abusing women are notoriously recounted by N.W.A. on the I99I album Efil4Zaggin ("Niggaz4Life" spelt backwards). Many more rappers make passing reference to their pimp properties, tapping into a long-standing matrix of subcultural, popular-cultural, and folkloric inheritances. The divergent articulations of the pimp as trope and type point to the versatility of this misogynist, street-heroic figure. Alongside these artists are a smaller number of female gangsta rappers who perform the role of mythic, materialist, and often violent "hoe": the group Boss proffers the "Recipe of a Hoe" and the "Diary of a Mad Bitch"; and Hoes With Attitude are Living in a Hoe House, with tracks like "I-900Bitches" and "Trick iz a Trick" (advising women "Nine times out of ten, he ain't nothin' but a trick [john]"). For these female artists in a maledriven form, the central features of their hoe personae are materialism, their commodification of sex, and their rejection of romance-based courting rituals. Without question then, highly performative pimping and hustling themes pervade gangsta ethics and aesthetics.

In what follows, I will discuss three of the most important pimpidentified gangsta rappers. First, I consider Too Short (Todd Shaw), whose star image rests almost exclusively on his pimp persona; and secondly, Ice-T (Tracy Marrow), whose music and image reflect the "pimpdafied" life style. Together they inaugurated gangsta rap's pimp aesthetic, their early albums catalyzing the market for lewd, West Coast, 
story-telling rap. As early as I986, several years before the "gangsta" subgenre was even so called, Too Short's Born To Mack sold over 500,000 copies (without an official distribution deal), as did Ice T's debut Rhyme Pays the following year. ${ }^{4}$ Notably, these albums constitute some of the earliest examples of hip-hop's geographic regionalization away from its original New York dominance. Finally, I will examine Ice Cube (O'Shea Jackson) who in many ways eschews the pimp image. Yet, his explications of the pimp trope are among the most sophisticated and interesting. Thus, I will move from conspicuous to more coded enunciations of the pimp figure in gangsta rap. Along with LL Cool J, these three rappers were for many years the most consistently best-selling solo artists in rap, rendering them particularly significant and influential. ${ }^{5}$ I will be focusing on the earlier material of these prolific artists, because it is here that the themes and relationships I want to explore are most apparent.

Through an engagement with the formal vocabularies of the pimp, I will explore the little-documented indeterminacies and metadiscursive imperatives of pimp poetics. In all cases, these enigmatic figures seem to privilege style over substance, image over reality, word over deedindeed, in the "post" move, the impulse is towards the substantiveness of style, and the performativity of language. Taking the stark misogyny in the lyrical content of these tracks as a fairly well-documented "given," I will focus instead on political ambiguities and semantic complexities which almost always also attend this music. I want to draw out the ways in which these texts, through their formal politics, comment on the discursive negotiation of power. It is worth stressing that my concern is not with real-life pimps and their practices as these might be reflected in gangsta, but with the highly mediated and emblematic black pimp figure. The underlying objectives of this article are to privilege the genre's neglected formal politics and pleasures, and also to demonstrate that gangsta rap, far from being a straightforwardly co-opted and debased form, comments in complex ways on the terms and conditions of its own popular and commercial-cultural mediation. There needs to be a greater engagement with the formal complexities of, and immense aesthetic pleasures derived from, these black lumpen repertoires, as they have transmuted into mass-mediated figures like the enigmatic mack of gangsta rap.

${ }^{4}$ Born to Mack (Dangerous Music, 1986); Rhyme Pays (Sire, 1987).

${ }_{5}$ As reported in Vibe magazine, April $1996,63$. 


\section{THE SIGNIFYING PIMP}

The pimp figure has long been associated with the trickster in AfricanAmerican vernacular traditions and it is above all the persuasive power, verbal skill, and emphasis on simulation which link the two. In their romanticized ethnographic study of Californian black pimps in the early I970s, the Milners explain:

Why should the pimp be a hero? ... First, the pimp is a trickster. By the use of wit and guile he earns a rich living and maintains aristocratic tastes without having to resort either to violence or to physical labor. ${ }^{6}$

Like gangsta rappers, the pimp and the trickster are expert "mackers": they earn a rich living from their wit, guile, and dextrous language use. The trickster extends back into nineteenth-century African-American folklore with animal types like Brer Rabbit, and, as scholars have traced, further back to the African tricksters Esu, Legba, and the spider Anansi. In what follows, I will concentrate on the more recent and closely related antecedents of black toasts. Workwing class and predominantly male, the black oral practice of toasting (the recitation, classically in the street, barber-shop, or prison, of extended narrative poems) shifted and modulated from the predominantly rural South to northern urban centres over the course of the twentieth century. Particularly pertinent to this discussion are the pimp toasts (notably "Pimping Sam," "The Lame and the Whore," and "The Pimp") and "Signifying Monkey." Folklorist Bruce Jackson summarizes their characteristic traits: the pimp's "verbal skill and sexual prowess", and the Monkey's "hipness" and skills of "manipulation." "The pimp tends to "play the dozens" (the black practice of verbal duelling and braggadocio) on the female because verbal mastery is equated with sexual dominance. The Monkey uses linguistic trickery and indirection to master an opponent. In both cases the power contest in the narrative is waged with words.

"Signifying Monkey" is a standard of African-American oral culture: from its antebellum origins, it has been continually repeated and revised. In the following version of the opening lines, from 1965 , the parallels between Monkey and pimp are (unusually) actualized:

Say deep down in the jungle in the coconut grove

${ }^{6}$ Milner and Milner, 27I. On the link between pimp and trickster see for instance Lawrence W. Levine, Black Culture and Black. Consciousness: Afro-American Folk. Thought from Slavery to Freedom (New York: Oxford University Press, 1977), 382-84.

7 Jackson, "Get Your Ass in the Water and Swim Like Me": Narrative Poetry from the Black. Oral Tradition (Cambridge, Mass.: Harvard University Press, 1974), 34, 28. 
lay the Signifying Monkey in his one-button roll.

Now the hat he wore was on the Esquire fold, his shoes was on a triple-A last.

You could tell that he was a pimping motherfucker by the way his hair was gassed. ${ }^{8}$

This version cashes out the equivalencies between pimp and Monkey, because of their shared association with dandified appearance. As the toast continues, the bored and playful Monkey tells the Lion (often coded as "Whitey") that the Elephant has "bad mouthed" or insulted him and his family, inciting the Lion to seek out the Elephant and challenge him. Consequently, the Elephant - who is physically superior - trounces the Lion, at which point the latter realizes that his mistake was to believe the trickery of the Monkey. As Jackson outlines:

"Signifying Monkey" is about a jungle trickster who by clever wordplay-signifying-manages to send his archfoe, Lion, to be stomped and mangled by the stately Elephant. The Monkey uses wile and cleverness to accomplish what he cannot accomplish with brawn: his mode is a verbal judo, for he uses his enemy's own excessive ego against him, and he does it all with words. ${ }^{9}$

My italics highlight the extent to which the action of the narrative turns on skilful language use: the Monkey exemplifies the phrase "brains over brawn." The Monkey and his rhetorical mode of "signifying" compellingly draw attention to the ambiguity and materiality of language.

The toast is often interpreted as a racial fable in which the dominant white character is outdone by the superior guile of the black protagonist: a discursive reversal of historically prevailing power relationships, and indeed of the racist stereotype which casts black as "brawn over brains." The tale is a parable par excellence of black America's celebrated improvisatory and innovatory skill. The fable crystallizes the tensions raised by this group's historic and enduring cultural and stylistic largesse (exemplified by the Monkey) combined with its low stock of political and economic assets (signalled by the white-coded Lion's greater might). Crucially, the third-party, "stately" Elephant stands for impersonal power that can be tapped into and channelled in various ways, thereby resisting any Manichaean reading of power relations in the toast. As Henry Louis Gates explains, "the three terms of the traditional mythic structure serve to dispel a simple relation of identity between the allegorical figures of the poem and the binary political relationship,

8 Victor, at Wynne (penitentiary), 20 August 1965, transcribed in Jackson," Get Your Ass in the Water," I62-63. " Jackson, "Get Your Ass In the Water," I 3-14. 
outside the text, between black and white. The third term both critiques the idea of the binary opposition and demonstrates that Signifyin $(\mathrm{g})$ itself encompasses a larger domain than merely the political."10

The term signifying, associated with this toast, means encoded and highly rhetorical black vernacular speech: in short, clever word-play. Geneva Smitherman summarizes the characteristic features of signifying: exaggerated language (unusual words); mimicry; proverbial statement and aphoristic phrasing; punning and plays on words; spontaneity and improvisation; image-making and metaphor; braggadocio; indirection (circumlocution, suggestiveness); and tonal semantics. ${ }^{11}$ Signifying operates in black urban language use and, as one of its dominant contemporary cultural manifestations, in rap music. It would be a fairly pointless, because axiomatic, exercise simply to demonstrate that rap involves signifying. Still, thinking about gangsta rap inside this vernacular frame may be instructive for two reasons. First, gangsta - because of its non-prescribed and offensive lyrics, coupled with its emergence in the I 980 s at a time of acute focus on language and identity politics - has tended to attract determinist and polemical readings that underplay the formal and rhetorical complexities of the genre. And, secondly, generative and interesting links exist between the gangsta pimp and the Signifying Monkey. ${ }^{12}$

Henry Louis Gates importantly reworked this toast in The Signifying Monkey: A Theory of African-American Literary Criticism. ${ }^{13}$ He sets up the Monkey as the archetypal figure of black semantics, and reads it through the comparativist prisms of black vernacular discourse and post-structural theory. He posits:

The Signifying Monkey is the figure of the text of the Afro-American speaking subject, whose manipulations of the figurative and the literal both wreak havoc upon and inscribe order for criticism in the jungle. ${ }^{14}$

This offers an enabling way into examining the formal vocabularies of gangsta rap's pimp aesthetic. I want to position the pimp as signifier (in both "black" and "white" senses of the word): that is, the Monkey of

10 Signifying Monkey: A Theory of African-American Literary Criticism (New York and Oxford: Oxford University Press, i 988), 70.

11 Geneva Smitherman, Talkin and Testifyin: The Language of Black America (Boston: Houghton Mifflin Co, 1977), 94.

12 The equivalence is actualized by early gangsta rapper Schoolly D, on the track "Signifying Rapper" (Smoke Some Kill, Jive Records, I988).

13 See also Gates, Figures in Black: Words, Signs and the 'Racial' Self (New York and Oxford: Oxford University Press, 1987), 235-76.

${ }^{14}$ Gates, Signifying Monkey, 42. 
black diasporic semantics who "wreaks havoc" on the signified. In the polarized critical climate of the late eighties and early nineties, it became a commonplace to cast (and lambaste) Gates' intervention as essentialist. There can be little doubt that he valorized, and even to some extent mysticized, the African-American vernacular heritage. Still, though Gates proposed a distinctively African-American theory of interpretation, it is not reducible to essentialism. In a strategic move, he valorized this black discursive repertoire in order partly to undercut essentializing notions of "blackness" - a category which too often has been fixed (both inside and outside the academy) as a bedrock of ontological essence, authenticity, and social realism. His rhetoical and positional project, like the account put forward here, countered certain pejorative assumptions circulating in intellectually elitist "Lit.-Crit." circles about the disinclination of black scholars to conduct, and the non-conduciveness of black texts to be subjected to the "rigours" of, theoretical readings. ${ }^{15}$ In what constituted a timely intervention, Gates' virtuoso vision of post-structural blackness pointed up the striking fit between vernacular discourses and contemporary theory, neatly signposted by the racially inflected alternative meanings of "signification."

\section{THE PIMP "LIFESTYLIZATION"}

I used to fuck young-ass hoes,

Used to be broke and didn't have no clothes,

Now I fuck top-notch bitches,

Tellin' stories 'bout rags to riches,

About a pimp named Shorty from the Oakland set,

Been mackin' for years and ain't fell off yet,

So if you ever see me rollin' in my drop-top Caddy,

Throw a peace sign and say, "Hey, Pimp Daddy!"

"I'm a Playa," Too Short

In eight lines, Too Short captures the themes, idiom, and iconography of what we might call the pimp "lifestylization" in gangsta rap. ${ }^{16}$ The

${ }^{15}$ For a classic critique of Gates, see Barbara Christian, "The Race for Theory," Feminist Studies, I4 (Spring 1988). For an authoritative and even-handed overview of these contentious debates, see Betsy Erkkila, "Ethnicity, Literary Theory, and the Grounds of Resistance," American Quarterly, 47 (Dec. 1995), 563-94.

${ }^{16}$ I have developed the term "lifestylization" in "Pimpin' Ain't Easy': Work, Play and 'Lifestylization' of the Black Pimp Figure in Early i970s America," Beyond Martin Luther King: Media and Culture, Race and Resistance, ed. Brian Ward (Gainesville: University Press of Florida, 2000). 
affluent "pimp daddy" is preoccupied with the conspicuous display of material wealth ("drop-top Caddy," "clothes," and "riches"). The commodification of women ("hoes," "top-notch bitches") by the supersexual pimp is recounted in the lewd vernacular. The dandified spectacle foregrounds the importance of impression management: naming ("a pimp named Shorty"); reputation (“ain't fell off”); and recognition ("throw a peace sign"). When the Milners describe the subcultural pimp as an "aristocrat" who is admired and recognized, they point to the acute purchase placed on reputation, appearance, and leisure. Too Short's pimp tableau creates a powerful (sonic) spectacle, so that the observer/listener publicly recognizes him by responding, "Hey, Pimp Daddy!." The player image is also displayed on album covers: Too Short's Born To Mack pictures him in a long, phallic convertible car; and his Short Dog's In The House (Jive, I990) is a cartoon illustration of the player life style of pimps, hoes, cars and cellular phones. Equally, Ice-T is photographed with car and sharp suit on the cover of OG: Original Gangsta (Sire, I 99I). Claims to luxurious living stemming from the pimp/hustler aesthetic - the refrain of money, "hoes," and material possessions - became a kind of mantra in gangsta rap.

The most influential referent for Shaw's pimp aesthetic is the 1973 Blaxploitation film, The Mack (directed by Michael Campus). Set in Oakland, this low-budget, popular movie about a heroic pimp named "Goldie" (Max Julien) made a strong impression on the young, entrepreneurial Todd Shaw. He witnessed the powerful, rather nostalgic impact the film continued to have in i980s Oakland, elevating the pimp to the status of exalted hero:

When I moved up here, I noticed that a lot of people looked like pimps, yunno, they were dressing like pimps, acting like pimps, talking like pimps, wanting to be pimps. A lot of them were pimps, a lot of them weren't, but it was a pimp thing. ${ }^{17}$

Interestingly, he seems to make little distinction between those who "were pimps" and those who were only "acting like pimps." Equally, he explains on the track "Hoes," "I ain't givin' bitches no kinda slack/'Cause Oakland, California's, where they made The Mack." He tellingly invokes the movie rather than actual pimps to call up an authentic sense of place. Clearly both real pimps and popular-cultural referents like Goldie inform this subcultural style: what Shaw describes elusively as the "pimp thing."

\footnotetext{
17 Quoted in Fernando, New Beats, i I4.
} 
For Ice-T, it was the legendary pimp Iceberg Slim (Robert Beck) who inspired him to convert his "fast-track" life style into rap rhymes, just as Slim had turned his pimping experiences into autobiographical fiction:

Ghetto hustlers in my neighbourhood would talk this nasty dialect rich with imagery of sex and humor. My buddies and I wanted to know where they picked it up, and they'd told us, "You better get into some of that Iceberg stuff!"18

The influence of Iceberg Slim's literature on black urban culture has been considerable. The Holloway House edition of Pimp has sold well over one million copies, and the Milners note that the book "was read by the majority of pimps." ${ }^{19}$ Dynamic intersections emerge between subcultural, pop-cultural, and occupational realms (Pimp as both professional and style manual) and complex referential dynamics are mobilized between them. Gangsta is one of the most mediated mass-cultural forms of pimp culture, in which "retro-mack" rappers openly acknowledge and celebrate their fictive forefathers. ${ }^{20}$ While Ice-T often claims that he was once a pimp, middle-class Too Short does not. In interview, he explains that the Too Short persona is "just a cool little hustle" and "a marketing vehicle.",21 That he has never actually lived "the life" and that Ice-T no longer does are not cause for shame or embarrassment, because rapping, like pimping, is constructed as an entrepreneurial pursuit. It is worth stressing that the critical tendency simply to present gangsta lyrics as evidence of lived experience (as an "address to truth") is certainly ill-advised in light of the conspicuous reflexivity and complexity in these popular-cultural forms. If anything, The Mack and Pimp furnished these aspiring gangsta artists with narrative initiations into pop-cultural production rather than actual pimping.

As subcultural studies have explored, youth, especially male youth, invests heavily in stylized signs of group identity. Oakland's pimp culture, according to Shaw, privileges the signifying practices of dressing, acting, talking, walking, which all coalesce in complex and overdetermined ways around the fantasized desire of wanting to be pimps. The pimp constitutes an icon of upward mobility for black working-class males, spectacularly

18 Introduction to the new edition of Pimp: The Story of My Life, Iceberg Slim (Edinburgh: Payback Press, I 996), v.

19 Sales figure from Peter A. Muckley, "Iceberg Slim: Robert Beck - A True Essay at a BioCriticism of an Ex-Outlaw Artist," Black Scholar, 26: I (1996), i 8; Milner and Milner, Black Players, 39.

20 "Retro-mack" is William Eric Perkins' term, see Droppin' Science (Philadelphia: Temple University Press, 1996), 24-28.

21 Quoted in Fernando, New Beats, i I4, i I 5. 
refusing, through their heightened style politics, the subservient typecasting that has historically been imposed by the dominant social order. African-American working-class culture has long been associated with sophisticated forms of stylization, and with "a deeply entrenched ethic of conspicuous consumption." 22 Stuart Hall remarks, "within the black repertoire, style - which mainstream cultural critics often believe to be the mere husk, the wrapping, the sugar coating on the pill - has become itself the subject of what is going on." He goes on to characterize the signs of diasporic blackness, echoing Shaw's observations, as the "linguistic innovations in rhetorical stylization of the body, forms of occupying an alien social space, heightened expressions, hairstyles, ways of walking, standing, and talking." ${ }^{23}$ Thus, the pimp figure can be read as a preeminent figure of diasporic black stylization.

In gangsta pimp narratives, life style often subsumes occupational imperative. Ice-T registers this when he explains that pimpin' is "also used as a definition of a fly, cool lifestyle, which has nothing to do with prostitution." The semantic shift is also noted by Roger D. Abrahams: "Pimp - originally a procurer, but because of the style of this profession, now used among this group to refer to any 'smart' person." 24 These comments suggest that certainly for gangsta rap, and indeed for the subcultural and entrepreneurial imagination the genre emerges from, the pimp image is more central than his occupation. While this emphasis on lifestylization does not mitigate the mack's regressive gender politics, it does pose interesting questions about the relationship between occupation and performance, between culture and commerce. Historian Robin Kelley has argued that the boundary between work and play in American urban centres is highly permeable and should not be "dichotomized." Kelley insists that urban play is "more than an expression of stylistic innovation, gender identities, and/or racial and class anger - increasingly it is viewed as a way to survive economic crisis or a means to upward mobility." 25 The mythic pimp, like the rapper, is able to convert subcultural capital into economic capital. A feed-back loop emerges: the pimp logic is in order to get something you need to look like you've already got something. Thus, street-

${ }^{22}$ Shane White and Graham White, Stylin': African American Expressive Culture from Its Beginnings to the Zoot Suit (Ithaca and London: Cornell University Press, I998), 243.

${ }^{23}$ Stuart Hall, "What Is this 'Black' in Black Popular Culture?" in Gina Dent, ed., Black Popular Culture, (Seattle: Bay Press, 1992), 27, 28.

${ }^{24}$ Ice-T, Ice Opinion, 199. Abrahams, Deep Down in the Jungle: Negro Narrative Folklore from the Streets of Philadelphia, rev. edn (Chicago: Aldine Publishing, 1970), 263.

${ }^{25}$ Kelley, Yo' Mama's Disfunktional! : Fighting the Culture Wars in Urban America (Boston: Beacon Press, i 997), 45 . 
cultural style politics must not simply be considered in a separate and often resistive realm to occupational pursuits. In the deregulated, contemporary, urban America, the two sites are deeply interwoven.

I would argue that the pimp lifestylization in gangsta rap serves as a suggestive emblem for the rampant market capitalism and deregulation of I 98 os America more generally: the gangsta pimp is surely one of "Reagan's children." The ostentatious pimp figure captures some of the tensions between the cult of consumerism and individualism, on the one hand, and the deep insecurities and new flexibilities of the restructuring and contracting job market in the Reagan/Bush years, on the other. The young urban black men of gangsta rap - selling tapes out of the car boot, or notionally "selling pussy" - express a highly stylized entrepreneurial impulse. ${ }^{26}$ At the same time, the resurgence of pimp culture signals a deep material and symbolic investment in life style and leisure pursuits, which accompanies economic and employment frustration. In addition, the shifting gender roles and relations, fostered in part by the diminishing job opportunities for blue-collar men, may have something to do with the black hustling imagination of the i 980 s alighting on the misogynist and extremely patriarchal pimp figure. So, when Too Short attests that he is "tellin' stories 'bout rags to riches," he clearly recounts a time-worn American story of bootstrap success, which holds heightened and uneasy resonances for many young black men in the late-r 980 os.

\section{THE PERFORMATIVE PIMP}

Language-centred pimp poetics are predicated on self-referential storytelling. In the lines quoted earlier, Too Short embodies the irreverent pimp and then, without a moment's pause, becomes the rapper reflexively "tellin' stories" about being a pimp. This identificatory slippage between persona and rapper is typical of gangsta rhymes. The convention is for the rapper to embody and then, without explanation, to drop the chosen character and comment on that embodiment. The ease with which gangsta rappers play with their pimp personae - their deft shifts from narrative to metanarrative and back again - has much to do with the conspicuous affinities between the two roles. The Milners describe the pimp: "He is recognized as among the best talkers or 'rappers' in the hustling

${ }^{26}$ On economic restructuring, conservative social and economic policy, and increasing economic polarization in 1980 s Southern California, see Edward Soja, Postmodern Geographies: The Reassertion of Space in Critical Social Theory (London: Verso, 1989); Mike Davis, City of Quartz: Excavating the Future in Los Angeles (London: Verso, 1990). 
world." ${ }^{27}$ Pointing to a different set of equivalences, one critic asserts: "In the tradition of the player [pimp], the rappers' smooth talk can lead to fame, big bank rolls, fly cars, women and outlandish outfits." ${ }^{28}$ Rap artists share actualized equivalences with pimps, rendering these personae reflexive and slippery figurations.

Too Short, in the track "I'm a Playa," has "been mackin' for years": read, both literally rapping and fictively pimping. The repeated chorus refrain, "I'm a playa and I'm playin' just the bass," underlines the equivocatory status of the trickster. Too Short asserts that he is a "playa" (synonymous with "pimp") and then through repetition and revision, he undermines this meaning by asserting that he is only a rapper ("playin" just the bass"). He at once consolidates and deconstructs the integrity (just a performer) of his persona. Repetition and reversal is a key rhetorical device in vernacular signifying. Two signs share the same signifier (play), thus the power of the figure rests on homonymic indeterminacy. Gates explains:

signifying can also be employed to reverse or undermine pretense or even one's opinion about one's own status. This use of repetition and reversal (chiasmus) constitutes an implicit parody of a subject's own complicity in illusion. ${ }^{29}$

Too Short then is the pimp/trickster, calling attention to his own status as performer, that is, "his own complicity in illusion." He points up the formal dimensions of his rhyme. His word-play on the word play points to the metadiscursive imperatives of the Signifying Monkey.

In all gangsta rap tracks there are two performances going on simultaneously: the action of the (usually first-person) character within the narrative, and the rhetorical action of rapping itself. That is, the performance in the text and the performance of the text. The rapper selfconsciously plays with these two performance sites so that they work in and through each other. For the pimp-identified gangsta rapper, the dual activities are linguistic and sexual: it is through words (the rhetorical performance) that he establishes his sexual prowess (the performance within the narrative). The "freaky" tales of Ice-T"s first album, Rhyme Pays, illustrate this kind of performative logic. "I Love Ladies" begins when Ice-T "seen this fly girl walkin' down the street":

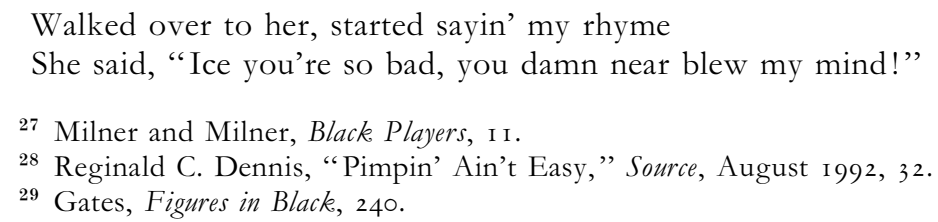


I kept on rappin', runnin' my mouth

The next thing I knew I was at her house.

This rap sets up the "establishing shot" for the comic sex scenes to follow. Ice-T's verbal seduction ("sayin' my rhyme," "kept on rappin," "runnin' my mouth") proves efficacious, so that Ice gets his girl. It is with the demonstration of verbal skill that he establishes at once his rapping and his sexual prowess. The pre-eminent position of language in these raps has a close precedent in the pimp toasts, as Jackson explains:

verbal agility is often the basis of contest between the pimp and whore: he first bests her in an insult or bragging session, and then superfucks her into adulating respect for "that too." His words are his plumage. ${ }^{30}$

Sexual expertise rests on the plumage of rhetorical expertise.

The consequent bedroom scene in "I Love Ladies" centres on the bodacious "shit talkin"” of Ice-T"s rhyme:

This girl meant business I had no doubt

This is just about the time that The Ice passed out.

The next day I woke the girl was through,

Room still smokin', my legs black and blue.

Interestingly, and most unusually for gangsta, it is the woman who "superfucks" Ice-T. He does not denigrate, but rather enjoys, the sexually active female - indeed this provides the basis for his boast. The rapper's "manhood" is not compromised because emphasis rests on the potency of his linguistic rather than sexual performance. The story is humorous and overblown, so that attention is drawn not to the realism of the narrative action but instead to the way in which the story is told. The principal action has taken place in the verbal domain, so that to "talk the talk" is to "walk the walk."

This type of rap is performative in a number of ways. Most conspicuously, there is an emphasis on the sexual performance of the story and the rhetorical rapping performance itself. Moreover, the "performative" in Speech Act Theory is the discursive practice that brings about or constitutes that which it names. It is concerned with the efficacy of language, as Judith Butler lucidly explores in Excitable Speech: A Politics of the Performative. Thus, the emphasis placed on the way in which the speech is rapped works to materialize the boasts. The performativity of language - the conflation of word and action - works in two ways. Speech acts can be "illocutionary" (in saying at the same time they do what they say) or they can be "perlocutionary" (in saying they initiate

\footnotetext{
30 Jackson, "Get Your Ass in the Water," I 7.
} 
temporally removed consequences). ${ }^{31}$ Perlocutionary effects are clearly enacted in the pimp/trickster tales: just as the Monkey can "effect" the Lion's death through words and the pimp can "master" the whore through smooth talk, so the rapper's rhymes can earn a rich living ("rhyme pays"). However, it is the illocutionary imperative, in which speech is act, that is strikingly developed in gangsta's pimp rhymes, as with Ice-T's rhyme above. A heightened investment in performative language has long been a feature of African-American vernacular discourse. As linguist Geneva Smitherman explains:

While the speakers may or may not act out the implications of their words, the point is that the listeners do not necessarily expect any action to follow. As a matter of fact, skilful rappers can often avoid having to prove themselves through deeds if their rap is strong enough. ${ }^{32}$

Rap constitutes deed: as Ice-T asserts on The Iceberg, "My Word is Bond." The performative imperative of these language-centred practices (the materialization of that which is named) comes to serve as a metaphor for the very material perlocutionary consequences of language: sex and cash.

\section{WHO'S THE MACK?}

Macking is the game and everybody's playing And as long as you believe what they saying Consider them a M.A.C.K. and with no delay They are gonna get all the play

"Who's the Mack?," Ice Cube

So far I have traced the emphasis on style, language, and performativity which make up the pimp/trickster aesthetic in gangsta rap. Through an extended reading of the hit single, "Who's the Mack?" (I99I) by Ice Cube, I want to consolidate this discussion of signification and at the same time to extend it into questions of identification. The quotation above turns on the play between the literal and the figurative. That is, the distinction between those who "believe what they saying" (the Lion, or those who understand only apparent meanings), and the "M.A.C.K." (the Monkey who gets "all the play," that is, all the power because s/he can manipulate the syntactic and semantic realms of language, betokened here by the spelling out of the letters). This tension lies at the centre of the black vernacular practice of signifying, as anthropologist Claudia MitchellKernan explains: "The apparent significance of the message differs from its real significance. The apparent meaning of the sentence 'signifies' its

31 Butler, Excitable Speech (London and New York: Routledge, I997), I-42.

${ }^{32}$ Smitherman, Talkin and Testifyin, 83. 
actual meaning. " 33 The mack is an emblematic trickster who occupies the space between the literal and the metaphoric domains. Rather than ontological essence, the mack (like the Monkey) draws attention to the performative and contingent nature of identity construction. Gates posits:

[T] he Signifying Monkey - he who dwells at the margins of discourse, ever punning, ever troping, ever embodying the ambiguities of language - is our trope for ... chiasmus itself, repeating and reversing simultaneously as he does in one deft discursive act. ${ }^{34}$

Thus, pimp poetics share affinities with post-structural notions not only of signification but also of subjectivity, whereby the mack serves as an emblem of ontological indeterminacy.

Ice Cube is one of the most powerful and playful story-tellers in rap music. Although he rejects the flashy style of the pimp ("I don't wear too much gold 'cause it's tacky," "Who's the Mack?"), Cube remains a preeminent macker qua trickster. For critics, his rapping virtuosity is often seen to rest on his rhetorical versatility: "He can veer from unlettered gangsta bluster to racial cant to sentimental reflection to prodigious cultural literacy without missing a beat of his deep funk grooves. ${ }^{\prime 35}$ This characteristic commentary expresses Cube's verbal dexterity and identificatory flexibility. It is above all the agility and provocation of his lyrical and tonal poetics that mark off Ice Cube as macking supremo. Like the tricksters of the toasts, he is "adroit at role-playing" and "can assume a variety of faces for a variety of situations." 36

In "Who's the Mack?," Cube offers various circumlocutory " answers" to this rhetorical question which frames each verse. As in Signifying Monkey toasts, there are three actants, two present and one absent, but tension has switched from (an implied) racial to gender difference. Cube, the subject, is addressing the manipulated female in the second-person ("He'll have your ass in and out of every car / with every Ron and Rick, sucking every john's dick"), at the same time as he describes the pimp in the third person:

Rolling in a fucked-up Lincoln

Leaning to the side so it looks like he's sinking

Into that leopard interior

This nigga thinks every girl's inferior

To his tongue

${ }^{33}$ Mitchell-Kernan, "Signifying, Loud-talking, and Marking," in Thomas Kochman, ed., Rappin' and Stylin' Out: Communication in Urban Black. America (Chicago and Urbana: University of Illinois Press, 1972), $326 . \quad{ }_{34}$ Gates, Figures in Black, 236.

35 Steven Daly and Nathaniel Wice, alt.culture: An A-to-Z Guide to the 'gos (New York: HarperCollins, I995), I09. $\quad{ }^{36}$ Jackson, 'Get Your Ass In the Water', 32. 
Cube depicts the stereotypical pimp (the big hat, the car, the "gangsta lean," the good rap) enlisting and exploiting the female prostitute with his persuasive oral powers. Because the whole verse is framed as an extended question - as one possible answer to the question posed - a measure of circumlocution is conferred on the narrative. Yet, the heightened and lewd narrative images coax the listener into a determinate interpretation of the lyrics.

Recalling the Milners' connotative definition of the term "Mack" "the line, the 'rap,' the psychological game"-the manipulatory techniques of the pimp's golden tongue are vividly evoked by Cube. The pimp in the narrative is the "M. A. C. K." with "all the play" because his trickery works on the woman. But as the narrative continues, an alternative power dynamic emerges between the three participants: one that points to the "direction through indirection" of the signifying rapper. Powerfully disrupting any simple reading of the dualistic power relationship between the pimp and the prostitute is the pre-eminent rhetorical presence of Ice Cube. Even as we are told in the content of the narrative of the pimp's "good rap," the oral virtuosity of Cube's rap makes its aural impact on the listener. Cube's distinctive rhyming patterns and phrasing are playful and quite sophisticated, founded on his unhurried, Southern-inflected vocal. He often comes in after the first beat of the bar:

$$
\begin{aligned}
& \text { "I wanna do it," but you feeling like a } \underline{\mathrm{H}}-\mathrm{O}-\mathrm{E} \text {, } \\
& \text { Cause the nigga ain't nothing but a rover, } \\
& \text { He grab your hand, you leave, and it's over, } \\
& \text { Ya knew the game and you still ended up on your back. } \\
& \text { Now ask yo'self, "who's the } \underline{\text { mack }} \text { " ? }{ }^{37} \text { wh }
\end{aligned}
$$

With ease, he shifts from punchy quavers ("You wanna do it but you feeling like a $\underline{\mathrm{H}}-\mathrm{O}-\mathrm{E}$ "), to quasi-triplets (in the metonymic phrase, " $\underline{\text { still }}$ ended up on your back"). A trademark Cube technique is to match a feminine to a masculine rhyme: thus he couples "unfold" with "earlobe," and "smile" with "buck-wild." These combinations of iambic and trochaic feet work to achieve a laid-back yet tight tonal inflection. Then, in a lyric littered with half-rhymes, the pivotal final refrain's masculine

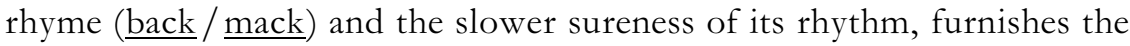
line with a great deal of force. In this way, the listener starts to get an indication of who the "real" mack is.

In the final verse of the track, Cube shifts from the mode of questioning to assertion, ostensibly "laying his cards on the table":

\footnotetext{
${ }^{37} \mathrm{My}$ underlining indicates stressed syllables.
} 
But when it comes to me, save the drama for your mama It's Ice Cube and you know that I'm a Mack in my own right

Cube declares his own ascendant macking status, "unlike Iceberg Slim" and the traditional pimps he has conjured in previous verses. Thus, on one level, the power relationship of the track is between pimp and prostitute (pimp tricks prostitute), but, on a second, formal level of meaning, it is Ice Cube who signifies on the pimp. Cube, like the Signifying Monkey "is a rhetorical genius" who is "intent on demystifying the Lion's selfimposed status as King of the Jungle." ${ }^{38}$ The pimp emerges as a stereotype, a literalized and static object of Cube's superior psychological game. In some ways, Cube may be critiquing the pimp's commodification: as this black subcultural figure has started to become a commercial formula, there is less space for formal experimentation, less space to "say something new," which may impede the repetition and crucial revision that has always been central to black vernacular expressive discourses. Indeed, he may well be "dissing" Too Short here! Mitchell-Kernan explains that "[m]etaphors ... may lose their effectiveness over time due to over-use. They lose value as clever wit." 39 Cube "schools" the woman (and by extension the listener), fulfilling one of Smitherman's "signifying" criteria of "teachy but not preachy," and in so doing constitutes himself as the mack.

Still, a reading of the track which positions Ice Cube as the "real" mack and other pimps as faux (in black idiomatic terms, the distinction between legitimate "representing" and phoney "fronting") would be too simple. The track ends with the repeated chant "straight gangsta mack" (referring to Cube) and he insists he is "giving up the facts." Yet, the circumlocutory track is far from "straight" nor is it "fact"-driven, so these ostensibly transparent assertions are further manipulations of the literal. In concert, Cube was reported to jettison his gangsta attire in order to perform "Who's the Mack?," dressing up suggestively in a mink coat, the sign of the conventional pimp. ${ }^{40}$ Finally, there is no one answer to the ontological question he poses because the question is more dialogic than dialectic. Smitherman describes this "convoluted style" of indirection at the heart of signifying: the "rapper will start with the point, then proceed to meander all around it; he may return circular fashion, to the point, but he typically does not proceed in a straight, linear, point-by-point

${ }^{38}$ Gates, Signifying Monkey, 56.

${ }^{39}$ Mitchell-Kernan, "Signifying, Loud-talking", 328.

40 Jonathan Gold, Los Angeles Times, 4 Aug. I990, F. 
progression." 41 Cube at once disclaims and underlines his macking credentials. Ice-T explains that "the typical person has a two-channel brain: Yes, no. Right, wrong. The objective of a pimp is to open this up to, 'Why not? Says who?' "42 These are the dissident rhetorical skills that subvert the binaries of the dialectical order.

The track's instrumentation evokes a pimp soundscape. Within the textual flow of the album, "Who's the Mack?" constitutes a reprieve from what critic David Toop calls the "hyperventilating fury" of the rest of Bomb Squad-produced AmeriKKKa's Most Wanted. ${ }^{43}$ The track's sloweddown samples of trumpet, keyboards, and acoustic flute strike a sleazy, seductive note. The minor-keyed flute riff complements the persuasive psychological techniques of the mack. The jazz-funk feel nostalgically positions the listener in the early-seventies (the "golden age" of pimp culture), at the same time as the sound is updated by the momentous bassline.

Asked to review the album for Village Voice, critic Joan Morgan - after initially refusing the assignment - called her piece "The Nigga Ya Hate To Love" (playing chiastically on the album track "The Nigga Ya Love To Hate"). ${ }^{44}$ The article adopts a confessional tone, structured as a series of "Snatches" (or brief scenes, as she familiarizes herself with the album), which trace her gradual "submission" to Cube's music. From a posture of antagonism ("I'm not the one trying to reconcile my black middle-class intellectual complex with wanna-be down ghetto romanticization"), she entertainingly tracks her denial and then emerging acknowledgement of the pleasures the album affords ("How the fuck could I remember to bring Ice Cube and forget my bag of black hair-care products?"). Her review constructs Cube as a kind of compulsion ("Seductive? ... Yes, Lord"). When Morgan attests, "[t]he sense of pleasure I feel is almost perverse," she configures herself as victim of the macking guile of the trickster who can manipulate the woman despite her "rational" resistance. ${ }^{45}$ The conceit of the article complements the rhetorical project of "Who's the Mack?": the female critic knowingly descending into the role of passive woman who "hates to love" her pimp. Interestingly, this begins to suggest positions opened up for female audiences by pimp

41 Smitherman, Talkin and Testifyin, $98 . \quad 42$ Ice-T, Ice Opinion, 85.

43 Toop, "High Tech Mindscapes," The Wire, January 1992, 34. Ice Cube, AmeriKKKa's Most Wanted (Priority, I990).

44 Morgan, "The Nigga Ya Hate to Love," originally printed in the Village Voice, I 7 July I 990; reprinted in Adam Sexton, ed., Rap on Rap: Straight-up Talk on Hip-Hop Culture (New York: Delta, i 995), I I 8-24. $\quad 45$ Ibid., I I9, I 2 I, I 22. 
culture. The potential pleasures received, all be they "bad pleasures," start to explain why, of all the gangsta rappers, it is the pimp-related ones that enjoy substantial female followings. Critic Reginald Dennis notes that "[e]ven the women love" Too Short: "they buy his records and fill the front rows of his concerts at every opportunity." 46

Gates explains that it is the "relationship between the literal and the figurative, and the dire consequences of their confusion, which is the most striking repeated element" of trickster tales. ${ }^{47}$ In gangsta rap, not only is the prostitute in danger of reading the pimp's promises literally, but the listener is proffered the precarious task of "correctly" deciding between literal and figurative, narrative and formal, sonic and visual, decodings of this provocative music. As a mass-mediated, massdisseminated form, gangsta transposes the street exchange and the original trinary relationship (between Monkey, Lion, and Elephant) into new spatially dispersed contexts of decoding. Black hermetically sealed readings of these tracks are therefore insufficient. The commodified performance of the gangsta pimp is endlessly repeatable in bedrooms, cars, and clubs across the globe (and over 70 per cent of those who bought rap records in the early i 990 s were white). ${ }^{48}$ Thus, from the proximity of the toast's street performance, the mass-mediated conditions of gangsta open up complex new modes of address. New identificatory positions emerge, such as those taken up by white suburban males or indeed the black middle-class female critic, Joan Morgan. This radical recontextualization of the performance situation opens up an interesting range of candidates for the role of the Lion. The too-literal Lion (outraged by the provocative words of the Monkey) offers a suggestive metaphor for thinking about the determinist readings and critical condemnation of the genre's profane lyrics. Calls for censorship work inadvertently to augment interest and record sales, so the Monkey may still be capitalizing on the Lion's ire. In any case, the new mediated and commercial conditions of production, reception, and consumption do not seem to reduce the explanatory resonance of this folkloric parable. The flexibility and pragmatism of the trickster embrace the diasporic potential for misreading and multiple-reading, which the commodification of vernacular forms elicits. As George Lipsitz's article on creative misunderstandings in

46 Dennis, "Pimpin' Ain't Easy," 33. $\quad 47$ Gates, Signifying Monkey, 55.

48 A survey found that 74 per cent of rap sold in the first six months of 1992 was bought by whites, as reported in the Los Angeles Times, ig July i992, 44. 
intercultural communication is entitled, “It's All Wrong, but It's All Right." "49

A struggle for power fuels the trinary relationships in "Who's the Mack?," a struggle waged in and through language. As such, mack serves as a generative and timely metaphor which, from its base in AfricanAmerican repertoires, can be cashed out in a range of contexts. The video for "Who's the Mack?" explores some of the term's multiple applications, refusing any single reading of who the mack is. Images of the seventies Blaxploitation pimps wearing big hats and long coats populate the video, interspersed with shots of Cube with the subtitle "straight gangsta mack." Towards the end, we see then-President Bush playing golf (again, emphasis is on life style) with the sign "President Mack." The politician's rhetorical power allows him to get "all the play" in a commensurate way to the dandified pimp on the street, through the ability to manipulate language. Macking is indeed the game that "everybody's playing" in spectacle- and rhetoric-driven contemporary America. Thus, the video makes an interesting de-essentializing move: the mack metaphor transcends racial boundaries and, in this case, sets up a patriarchal nexus. The video also mobilizes a critique of American politics by refusing the distinction between legitimate and illegitimate discursive power moves (between pimping and politicking). This is underlined by the image of a distorted US flag (on which stars are replaced by the skulls of piracy). Still, one might argue that such imagery serves to validate the pimp's exploitative practices within a capitalist patriarchal frame at least as much as it works to censure mainstream society.

Judith Butler sums up the performative, transposed from its linguistics base, as "the discursive mode by which ontological effects are installed." "50 Language - serving, as it customarily does, as trope for all socializing regimes-makes us who we are. Cube's slippery selfreferencing and representational play offer timely articulations of discursively installed identity. Gates describes the Monkey: "He exists to embody the figures of speech characteristic to the black vernacular. He is the principle of self-consciousness in the black vernacular, the meta-figure itself." ${ }^{11}$ The performative mack, the meta-figure, seems to enact and yet post-structurally evade the dictum that language speaks us.

49 Lipsitz, in Avery F. Gordon and Christopher Newfield, eds., Mapping Multiculturalism (Minneapolis: University of Minnesota Press, I 996), 403-1 2.

50 Cited in Let's Get It On: The Politics of Black Performance, ed. Catherine Ugwu (Seattle: Bay Press, i 995), i 7 .

51 Gates, Signifying Monkey, 53. 


\section{CONCLUSION}

"Blackness" - most particularly male, lower-class blackness - has long been constructed and understood through types of performance, masquerade, and spectacle. Du Bois' "double-consciousness," Ellison's "invisible man," and the Monkey/trickster types are only a few notable components in this black-diasporic repertoire. I have tried to demonstrate that the black pimp figure serves as well as his more legitimate relations as an expression of the tradition. The relentless drawing of attention to the codes and means of representation marks off this type as profoundly metadiscursive. The productive ambivalence and reflexivity of pimpidentified gangsta rap at once invite and guard against determinist readings. It has been in a strategic move, to counter the prevailing view which tends to read the politics of these gangsta artists as unequivocal and determinist, that I have pursued a critical line of inquiry. Still, however well the pimp may fit into certain contemporary critical paradigms, we must be wary of simply celebrating the semantic openness of the trickster. To be sure, certain strands of today's post-polemical theoretical climate privilege the deftness of the Monkey over the determinism of the Lion. The emphasis on play and performance works to evade finalized readings, which can be understood as both a productively open and an a-political, "lumpen" posture. That the gangsta-pimp draws attention to the methods and means of his own exploitative practice indicates both a dissident philosophical intent and a frank celebration of manipulative

conduct. Reflexivity both undermines and underwrites the status quo, to some extent providing only a mystifying, formal level as secondary complement to the regressive lyrics.

Informing the pimp figure is a range of competing inheritances that gangsta rappers draw on to produce a range of pimp-identified types, which are, in turn, decoded in widely divergent ways. In the customary commercial feed-back loop, audiences also influence production. Once the sales-demographic profile of gangsta music started to be registered and catered to, the knowing gangsta artists became increasingly well-attuned to the lucrative youth market's fascination with such thrillingly outré, "real," and subversive themes. Gangsta rap is, first and foremost, a component of the entertainment industry. Paul Gilroy rightly reminds us that, with the globalization of vernacular forms, "these communicative gestures are not expressive of an essence that exists outside of the acts which perform them and thereby transmit the structures of racial feeling 
to wider, as yet uncharted, worlds. "52 In light of these complex processes, I am not sure how useful it would be to draw conclusions as to a single or even overriding politics of the gangsta pimp as either subverting or reinforcing dominant culture. I have tried to show that both impulses are at work. The form is overdetermined and this leads to indeterminacies that are almost always built into the form.

There may be a touch of essentialism in my presentation of a preferred reading of the pimp, which emphasizes the genre's black cultural lineage. Of all the black archetypes mobilized in gangsta, the pimp figure has, probably most fully, resisted the dynamics of mainstream incorporation, market co-optation, and white imitation. To appropriate Tricia Rose's title, the black pimp figure, in all its "lifestylized" egregiousness, is surely "A Style Nobody Can Deal With." ${ }^{53}$ Moreover, to engage with the black repertoire of pimp tricksterism is always at the same time to undercut an essentialist position, since this enigmatic type is precisely constituted performatively. Michael Eric Dyson captures this paradox when he speaks of gangsta's "essential constructedness" and "literal artifice." oxymoronic phrases point to the ontological and interpretive problematics mobilized by the pimp aesthetic, which I have tried to draw out by mapping black cultural repertoires on to post-structuralist ideas. The pimp/trickster emerges as a profoundly diasporic figure, whose performativity and play offer intellectually productive and often humorous counterpoints to the smutty, regressive lyrics of misogyny and sexual domination.

\section{Copyright acknowledgements}

"I'm a Playa" ('T. Shaw/G. Clinton Jr./W. Collins/W. Frank) (C r 993 Zomba Songs Inc./Srand Music (all rights on behalf of Srand Music administered by Zomba Songs Inc.)

"I Love Ladies" (Marrow/Glen) (C) 1996 by kind permission of Universal/MCA Music Publ. Ltd. and (C) 1987 Colgems-EMI Music Inc. and Rhyme Syndicate Music (25\% EMI Music Publishing Ltd., London wC2 HoEA. Reproduced by permission of International Music Publications Ltd.

"Who's The Mack?" (words and music by Ice Cube/James Brown/Fred Wesley/St. Clair Pinckney) (C I 99 I Gangsta Boogie Music, WB Music Corp., Dynatone Publishing Co. and Unichappell Music Inc., Warner/Chappell Music Limited, London w6 8Bs. Reproduced by permission of International Music Publications Ltd.

${ }^{52}$ Gilroy, The Black Atlantic: Modernity and Double Consciousness (London and New York: Verso, г 993), г го. $\quad{ }^{53}$ Rose, in Mapping Multiculturalism, 424-44.

${ }^{54}$ Dyson, Between God and Gangsta Rap: Bearing Witness to Black Culture (New York: Oxford University Press, 1996), 179. 